\title{
Phospholipid Measurement
}

National Cancer Institute

\section{Source}

National Cancer Institute. Phospholipid Measurement. NCI Thesaurus. Code C96623.

The determination of the amount of phospholipid present in a sample. 